\title{
MODEL PENJARINGAN ASPIRASI MASYARAKAT SEBAGAI UPAYA PENINGKATAN KINERJA ANGGOTA DPRD
}

\author{
Budi Setiawan ${ }^{1}$, Muh. Alfian², S. Eko Putro Widoyoko ${ }^{3}$ \\ Universitas Muhammadiyah Purworejo, Jl. K.H. Ahmad Dahlan 3 \& 6 Purworejo \\ E-mail : setiawanbudi75@gmail.com
}

\begin{abstract}
ABSTRAK. Persoalan yang lazim terjadi adalah pemahaman dan kecenderungan sulitnya membina hubungan antara legislator (anggota Dewan terpilih) dengan rakyat sebagai konstituen. Persoalan ini menjadi kendala komunikasi antara Dewan dengan rakyat yang diwakilinya, dan berdampak pada rendahnya produk regulasi yang dihasilkan oleh lembaga legislatif atau Dewan Perwakilan Rakyat Daerah. Permasalahan penelitian ini adalah belum disusunnya sistem penjaringan aspirasi masyarakat yang dapat menjadi pedoman bagi anggota DPRD untuk melaksanakan penjaringan aspirasi masyarakat. Berdasarkan permasalahan tersebut, maka tujuan penelitian ini adalah mengembangkan alternatif model penjaringan aspirasi masyarakat beserta panduan dan format laporan penjaringan aspirasi masyarakat. Penelitian ini merupakan penelitian pengembangan menggunakan acuan dari Plomp dengan langkahlangkah: preliminary investigation, design, realization/construction, test, evaluation and revision, and implementation. Subjek uji coba adalah anggota DPRD Kabupaten Purworejo. Ujicoba dilaksanakan di dua daerah pemilihan. Proses pengembangan dilakukan melalui tiga tahap. Pengumpulan data menggunakan metode inventori sikap dan rating scale. Analisis data menggunakan deskriptif kualitatif. Berdasarkan hasil analisis data dapat disimpulkan bahwa: a) penjaringan aspirasi masyarakat dapat dilakukan dengan model: perorangan, melalui Partai Politik, kelompok sesuai dengan komisi yang di duduki, bersama-sama dengan anggota DPRD di daerah pemilihan, dan model penjaringan aspirasi yang dilakukan bersamaan dengan kegiatan musrenbang; b) hasil penilaian pakar, pemakai, maupun anggota dewan menunjukkan bahwa panduan dan format laporan penjaringan aspirasi masyarakat dinilai cukup baik sebagai acuan penjaringan aspirasi masyarakat bagi anggota DPRD Kabupaten Purworejo. Berdasarkan temuan tersebut maka panduan penjaringan aspirasi masyarakat hasil penelitian ini dapat dijadikan alternatif bagi anggota DPRD Kabupaten Purworejo dalam melakukan kegiatan penjaringan aspirasi masyarakat.
\end{abstract}

Kata kunci: penjaringan, kinerja, reses, aspirasi, konstituen

\section{THE PUBLIC ASPIRATION GATHERING MODEL AS THE EFFORTS OF A MEMBER OF PARLIAMENT DISTRICT}

ABSTRACT. The common issues are the understanding and the tendency of difficulties to build relationships between legislators (elected council members) and the people as constituents. These become communication problems between the Board and the people it represents, and adversely affects the products of regulations produced by the legislature or Legislative Council. The research problem is the unformulated public aspirations system that can serve as guidelines for members of parliament to carry out public aspirations. Based on these problems, the aim of this study is to develop an alternative model of public aspirations gathering along with guides and the reports format of public aspirations gathering. This study is a development research using benchmark of the Plomp, which steps are : preliminary investigation, design, realization/ construction, test, evaluation and revision, and implementation. The subjects are Purworejo legislators. The test will be conducted in two constituencies. The processes of development are through three stages. Data collection methods use attitude inventory and rating scale. Data analysis use descriptive qualitative methods. Based on the analysis of data, it can be concluded that : a) public aspirations gathering can be done with the model : individual, through political parties, groups in accordance with the commission in occupied, together with members of Parliament in the constituency, and the model of aspirations gathering is performed in conjunction with "musrenbang" activities, b) the results of expert assessment, the user, as well as members of the board indicates that guide and format the report public aspirations assessed quite well as a reference for the public aspirations gathering for legislators in Purworejo. Based on these findings the public aspirations gathering guide, this research results can be used as an alternative for legilstors in Purworejo to conducting public asprations gathering activities. Key words : networking, performance, recess, aspirations, constituents 


\section{PENDAHULUAN}

Perkembangan demokrasi di Indonesia memperlihatkan adanya dorongan pada pemerintahan rakyat. Rakyat mempunyai kedaulatan yang tertinggi, dengan sistem politik yang demokratis sehingga seluruh kebijakan dan aturan yang mengikat rakyat dilaksanakan dengan persetujuan rakyat. Persetujuan Rakyat di peroleh secara langsung melalui: (1) Pemilihan umum; (2) Referendum; dan (3) Konsultasi publik (pembuatan kebijakan partisipatif).

Salah satu agenda yang penting dalam melakukan perubahan politik adalah menyelenggarakan pemilu. Makna pemilu yang paling esensial bagi suatu kehidupan politik yang demokratis adalah sebagai institusi untuk melakukan perebutan kekuasaan (pengaruh) yang dilakukan dengan regulasi, norma dan etika sehingga sirkulasi elit politik (pergantian kekuasaan) dapat dilakukan secara damai dan beradab (J Kristiadi : 2004).

Pemilihan umum merupakan salah satu wadah yang bertujuan untuk memberikan kesempatan pada masyarakat untuk menentukan siapa yang akan mewakili mereka dalam lembaga legislatif dan siapa yang akan memimpin mereka dalam lembaga eksekutif. Hal ini menyebabkan rakyat menjadi elemen penting dalam pemilu terutama partisipasi dalam memilih wakilnya. Alfian menyatakan bahwa suasana demokratis akan tercapai atau terpenuhi bila mana ada dukungan masyarakat, sedangkan dukungan tersebut akan datang bila mana anggota-anggota masyarakat merasa kehendak-kehendak dan kepentingan-kepentingan mereka mendapat saluran yang wajar (Alfian : 1985). Sistem pemilu yang memberikan kesempatan bagi rakyat untuk memilih wakilnya dengan mulai sedikitnya peran partai politik, diharapkan menghasilkan wakil-wakil rakyat yang respon terhadap permasalahan yang terjadi di masyarakat dan menghasilkan kebijakan yang mencerminkan aspirasi masyarakat luas. Dan dengan sistem pemilihan seperti ini juga diharapkan akan muncul wakil-wakil rakyat yang dekat dengan konstituennya di daerah pemilihannya. Di mana wakilwakil rakyat yang duduk dalam Dewan
Perwakilan Rakyat inilah yang nantinya akan memperbaiki nasib masyarakat melalui kebijakan yang dihasilkannnya. Menurut David M. Olson (1974: 1), Legislatif atau Badan Perwakilan Rakyat adalah sebagai dasar suatu sistem politik demokrasi; bagian dari suatu komponen negara. Hukum yang tertinggi, pemegang hukum konstitusional, asal badan pembuat undang-undang. Mirip dengan yang disampaikan David M. Olson, Riswandha Imawan (2000:1) merumuskan bahwa DPR/DPRD adalah Lembaga Perwakilan Rakyat. Artinya, DPR/DPRD merupakan wadah di mana para wakil rakyat berbicara atas nama dan demi kebaikan rakyat. Karena itu yang paling diharapkan masyarakat dari para anggota Dewan adalah merasakan kepentingan rakyat sebagai kepentingannya sendiri. Bukan sebaliknya, mengalihkan kepentingan sendiri atas nama rakyat.

Kebijakan yang berorientasi terhadap masyarakat ini dihasilkan dengan jalan menampung aspirasi yang berkembang di masyarakat. Di mana untuk mendapatkan kebijakan partisipasif ini dilakukan melalui kegiatan komunikasi langsung terhadap masyarakat di daerah. Bentuk kegiatan ini dilakukan dalam masa reses dengan bentuk dialog-dialog dengan berbagai elemen masyarakat, kunjungan ke lapangan, dan mengumpulkan pendapat umum. Meski telah menempuh berbagai cara, seringkali keputusan yang diambil oleh anggota DPRD belum mampu mencerminkan aspirasi masyarakat luas. Hal ini memperlihatkan belum efektifnya informasi yang berasal dari masyarakat sebagai sebuah masukan dalam mempengaruhi pengambilan keputusan publik. Karenanya, penjaringan aspirasi masyarakat perlu lebih diefektifkan dengan melibatkan anggota DPRD secara langsung.

Kegiatan untuk menampung aspirasi masyarakat tersebut, dilakukan pada masa reses. Di mana kegiatan ini merupakan kewajiban yang harus dilakukan anggota DPRD sebagai bentuk pertanggung jawaban moral dan politis terhadap konstituennya. Kegiatan pada masa reses ini menjadi penting untuk memperkuat komunikasi dengan masyarakat secara langsung. Selain 
itu hal ini merupakan salah satu kewajiban anggota Dewan sesuai dengan yang di-amanatkan UU No. 22 Tahun 2003 pasal 18 yaitu memberikan pertanggung jawaban secara moral dan politis kepada pemilih dan daerah pemilihannya.

Ketidakefektifan penggunaan masa reses oleh anggota DPRD berdampak pada ketidakmampuan anggota DPRD untuk menjaring aspirasi, dan ini berdampak pada kinerja anggota DPRD. Kinerja anggota DPRD dapat menjadi ukuran apakah mereka mampu melaksanakan mandat yang telah diberikan rakyat kepada mereka (Bernardin dan Russel dalam Faustino Cordosa Gomes:2001). Kemampuan anggota DPRD dalam melakukan komunikasi dalam rangka penjaringan aspirasi masyarakat membuat citra anggota DPRD tidak cukup baik. Tidak tersalurkannya aspirasi masyarakat ini dapat disebabkan oleh ketidakmampuan anggota DPRD dalam melakukan komunikasi atau penjaringan aspirasi secara efektif. Di satu sisi, sebagian anggota DPRD merasa telah memenuhi kewajiban mereka dengan berkomunikasi langsung dengan konstituen. Sehingga kebutuhan akan sistem yang baku tentang model penjaringan aspirasi masyarakat yang diwujudkan dalam bentuk buku panduan sangat dibutuhkan oleh anggota DPRD, khususnya DPRD Kabupaten Purworejo.

\section{Potensi Luaran}

Potensi luaran yang dapat dihasilkan dari penelitian ini adalah semakin optimalnya kinerja anggota DPRD, karena semakin efektif dan produktifnya anggota DPRD dalam masa reses, yaitu dalam melakukan penjaringan aspirasi masyarakat. Lebih jauh luaran yang dapat diharapkan dari penelitian ini dapat memberikan kontribusi bagi peningkatan kemampuan anggota DPRD Kabupaten Purworejo untuk menjadi figur wakil rakyat yang memiliki intelektualitas tinggi, aspiratif, dekat dan dicintai konstituennya. Karena dari luaran yang diharapkan dari pembakuan sistem penjaringan aspirasi masyarakat maka pada akhir penelitian akan dihasilkan sebuah buku saku yang berisi panduan tentang model penjaringan aspirasi masyarakat. Buku yang dihasilkan tersebut diharapkan dapat menjadi salah satu referensi bagi anggota dewan untuk dapat menjaring aspirasi masyarakat secara efisien.

\section{Desain penelitian}

\section{METODE}

Penelitian ini merupakan penelitian pengembangan dengan mengadopsi model yang dikembangkan oleh Plomp yaitu model Research and Development atau "The $R \&$ D model" (Plomp, 1997).

Tahap pertama yang dilakukan adalah tahap investigasi awal (preliminary investigation) dan penyusuan desain. Pe-neliti melakukan investigasi awal dengan tujuan untuk mengetahui implementasi penjaringan aspirasi masyarakat yang telah dilakukan oleh anggota DPRD. Di samping itu, untuk mengetahui permasalahan-permasalahan yang muncul di lapangan berkaitan dengan pelaksanaan penjaringan aspirasi oleh anggota DPRD (aktivitas saat reses), serta tanggapan dan permasalahan yang dihadapi rakyat (konstituen) dalam penjaringan aspirasi. Setelah informasi awal diperoleh, dilakukan analisis dengan membandingkan konsep secara teoritis dan kenyataan di lapangan, maka disusun desain model sistem penjaringan aspirasi rakyat yang akan dikembangkan beserta perangkat dan buku panduannya. Desain model yang disusun merupakan draf awal dari model yang akan dikembangkan.

Setelah model sistem penjaringan aspirasi rakyat beserta perangkatnya berhasil disusun, maka dilanjutkan dengan validasi kepada para ahli (expert judgement). Ahli yang dilibatkan dalam validasi model sistem penjaringan aspirasi masyarakat oleh anggota DPRD meliputi: a). ahli dalam bidang metodologi penelitian dan komunikasi massa, b). ahli dalam bidang evaluasi dan penilaian kinerja, c). ahli dalam bidang politik, dan d). praktisi tokoh masyarakat (mantan anggota DPR/DPRD), e). pengguna model sistem penjaringan aspirasi rakyat yang dalam hal ini diwakili anggota DPRD. Proses validasi pakar atau ahli menggunakan model FGD (focus group discussion) dan 
Delphi untuk model dan buku panduan model. Penggunaan tekhnik Delphi (Delphi technique) dengan pertimbangan bahwa finalisasi model yang dikembangkan tidak semata-mata berdasarkan pada pemenuhan karakateristik model yang baik berdasarkan pengujian empirik, akan tetapi sangat penting mempertimbangkan pendapat atau penilaian pakar yang meliputi praktisi dan akademisi yang relevan. Tekhnik Delphi yang lazim digunakan dalam analisis kehijakan dan pengambilan keputusan, dalam penelitian ini digunakan untuk memperkokoh model, khususnya untuk pemantapan substansi.

Teknik Delphi sebagai pendekatan pengembangan model penjaringan aspirasi masyarakat di dalam penelitian ini difokuskan pada panduan penjaringan as-pirasi dan format laporan hasil penjaringan aspirasi. Teknik Delphi dilakukan sekali putaran untuk memperoleh penilaian dan masukanmasukan dari para ahli dan praktisi tentang konsep model panduan dan format laporan hasil penjaringan aspirasi yang dikembangkan.

Tahap kedua, yaitu tahap test, evaluation and revision. Pada tahap ini draf model sistem penjaringan aspirasi rakyat yang telah direvisi kemudian diujicobakan pada masa reses (penjaringan aspirasi). Data yang diperoleh dari hasil uji coba kemudian dianalis.

\section{Teknik Pengumpulan Data}

Pada penelitian pendahuluan, data dikumpulkan dengan metode wawancara dan observasi langsung. Pada proses pengembangan, data dikumpulkan dengan metode inventori dan rating scale.

\section{Subjek Uji Coba}

Subjek uji coba atau responden yang terlibat dalam penelitian ini terdiri dari anggota DPRD, Sekretariat Dewan, anggota masyarakat, dan pimpinan partai politik. diujicobakan oleh 10 anggota DPRD dalam minimal 3 daerah pemilihan.

\section{Analisis Data}

Analisis data hasil penelitian dilakukan dengan menggunakan dua pendekatan, yaitu kualitatif dan kuantitatif. Analisis kualitatif pertama dilakukan dengan mendeskripsikan dan memetakan hasil investigasi awal dan hasil FGD. Analisis data secara kualitatif kedua adalah dengan menganalisis data hasil validasi (penilaian) dari para ahli (expert) dan pemakai model (anggota DPRD), serta praktisi yang memberi masukanmasukan dalam rangka perbaikan model sistem penjariangan aspirasi masyarakat beserta perangkat dan panduannya. Analisis dilakukan terhadap panduan model dan format laporan hasil penjaringan aspirasi masyarakat.

Pada deskiptif data ini, data kuantitatif yang diperoleh melalui instrumen penilaian dicari skor reratanya kemudian dikonversikan ke data kualitatif dengan skala 5, dan akhirnya dideskripsikan. Berdasarkan hasil deskripsi tersebut dijadikan sebagai dasar untuk menentukan kualitas panduan dan format laporan penjaringan aspirasi masyarakat. Konversi data kuantitatif ke data kualitatif dengan skala 5 menggunakan aturan yang merupakan modifikasi dari aturan yang dikembangkan oleh Sudijono (2003: 329 - 339).

\section{HASIL DAN PEMBAHASAN}

\section{Pelaksanaan Penjaringan Aspirasi Masyarakat DPRD Kabupaten Purworejo}

Untuk mengetahui pelaksanaan dan permasalahan yang terkait dengan pengaringan aspirasi masyarkat DPRD kabupaten Purworejo, tim peneliti mengadakan eksplorasi sebagai bentuk investigasi awal. Kegiatan dilakukan di DPRD Kabupaten Purworejo. Informan terdiri dari satu orang perwakilan ketua komisi, 3 orang anggota dewan dan sekretaris dewan. Dari kegiatan tersebut diperoleh hasil sebagai berikut.

Pelaksanaan penjaringan aspirasi DPRD kabupaten Purworejo dilaksanakan baik secara formal maupun informal. Pelaksanaan secara informal dilaksanakan sepanjang waktu selama anggota DPRD Kabupaten Purworejo menjabat keanggotaan sebagai anggota DPRD. Pada pelaksanaan penjaringan aspirasi masyarakat secara informal tidak ada ketentuan waktu, model 
penjaringan ataupun laporan untuk hasil penjaringan aspirasi masyarakat tersebut. Model berkunjung dan menemui langsung konstituen adalah model penjaringan aspirasi yang dilakukan oleh anggota Dewan dalam bentuk informal. Model ini tidak terikat oleh waktu, namun juga tidak efektif karena metode dan dokumentasi sangat lemah.

Penjaringan aspirasi masyarakat secara formal dilakukan pada saat masa reses. Berdasarkan Keputusan DPRD Kabupaten Purworejo Nomor: 28/DPRD/2009 tentang Peraturan Tata Tertib DPRD Kabupaten Purworejo, masa reses merupakan rangkaian dari masa persidangan (Bab X, Pasal 67 ayat 3). Masa Reses dilaksanakan tiga kali dalam satu tahun dan paling lama 6 hari kerja dalam satu kali reses. Masa Reses dipergunakan untuk mengunjungi daerah pemilihan anggota yang bersangkutan dan menyerap aspirasi masyarakat. Setiap melaksanakan tugas reses anggota DPRD secara perorangan atau kelompok wajib membuat laporan tertulis atas pelaksanaan tugasnya yang disampaikan kepada pimpinan DPRD dalam Rapat Paripurna.

Kegiatan dan jadwal masa reses anggota DPRD Kabupaten Purworejo ditentukan oleh Pimpinan DPRD. Pimpinan DPRD Kabupaten Purworejo memberikan surat pemberitahuan untuk pelaksanaan tugas reses, setelah itu diserahkan sepenuhnya kepada masing-masing daerah pemilihan untuk berkoordinasi. Pengaturan ketentuan masa reses yang hanya melalui surat pemberitahuan ini menimbulkan banyak persepsi yang berbeda antar anggota dewan. Wilayah penjaringan aspirasi, tanggung jawab penyerapan aspirasi akhirnya menjadi pilihan yang berbeda antar anggota dewan.

Reses untuk mengunjungi daerah pemilihan dimaknai oleh anggota dewan sebagai wilayah penjaringan aspirasi mereka. Ada beberapa daerah pemilihan yang melaksanakan penjaringan aspirasi masyarakat secara bersamaan. Namun demikian ada sebagian daerah pemilihan yang tidak terkoordinasi sehingga pelaksananaan reses mereka adakan secara individual, dan untuk pelaporan kegiatan masa reses dilakukan secara berkelompok sesuai dengan daerah pemilihan. Pengumpulan aspirasi yang di peroleh oleh masing-masing anggota Dewan dikumpulkan dan di buat satu buah laporan untuk masing-masing daerah pemilihan.

Pelaporan yang dilakukan oleh masingmasing daerah pemilihan mempunyai format yang beragam sesuai dengan model masingmasing kelompok reses anggota dewan. Tidak adanya standarisasi format laporan masa reses menyebabkan beragamnya model pelaporan yang digunakan sebagai laporan masa reses oleh anggota dewan. Keragaman dan ketidakjelasan format ini menyebabkan tidak mudahnya pimpinan dewan, pimpinan komisi dan pemerintah daerah untuk memahami isi, arah dan maksud dari laporan kegiatan reses tersebut. Secara umum yang terlihat dari laporan masa reses dari masingmasing daerah pemilihan adalah kumpulan usulan program atau proyek pembangunan yang tidak diketahui asal sumber aspirasi tersebut. Analisa terhadap hasil kegiatan reses tersebut tidak kelihatan sehingga tidak mudah untuk dapat memahami seberapa penting program yang diusulkan oleh kelompok daerah pemilihan tersebut. Secara umum sistematika yang digunakan dalam penyusunan laporan kegiatan reses yaitu 1) Pendahuluan, 2) Dasar Pelaksanaan, 3) Lokasi \& Waktu Pelaksanaan, 4) Anggota Daerah Pemilihan, 4) Hasil Pelaksanaan Reses, 5) Penutup.

Hasil laporan kegiatan reses anggota DPRD Kabupaten Purworejo disampaikan kepada Pimpinan DPRD Kabupaten Purworejo melalui Rapat Paripurna dengan agenda Penyampaian Laporan Hasil Reses. Mekanisme ini memperlihatkan bahwa penyampaian atau pengawalan aspirasi masyarakat ujungnya adalah pada Rapat Paripurna DPRD Kabupaten Purworejo. Tugas anggota DPRD Kabupaten Purworejo sebagai penyalur aspirasi masyarakat seakan sudah gugur ketika sudah menyampaikan aspirasi masyarakat tersebut pada Rapat Paripurna Penyampaian Laporan Hasil Reses. Proses penyampaian dan pengawalan lebih lanjut terhadap aspirasi masyarakat masih sangat lemah, terlihat dari upaya DPRD yang hanya sebatas mengkompilasi 
hasil laporan reses anggota dewan untuk disampaikan kepada Pemerintah Daerah sebagai bahan Musrenbang. Hal ini berujung pada tidak adanya aspirasi masyarakat yang disampaikan melalui anggota dewan masuk dalam tema pembahasan dalam Musrenbang Kabupaten Purworejo.

Berdasarkan proses penjaringan yang telah berjalan sebelumnya beserta permasalahan yang muncul sebagaimana diuraikan di atas kemudian tim peneliti berusaha untuk memetakan dan menata modelmodel penjaringan yang dilaksanakan. Adapun hasil pemetaan dihasilkan bahwa model penjaringan aspirasi masyarakat yang telah berjalan adalah:

1. Model penjaringan aspirasi yang dilakukan secara perorangan.

2. Model penjaringan aspirasi yang dilakukan melalui Partai Politik.

3. Model penjaringan aspirasi yang dilakukan sesuai dengan komisi yang di duduki.

4. Model penjaringan aspirasi yang dilakukan bersama-sama dengan anggota DPRD di daerah pemilihan

Adapun penataan yang dilakukan adalah dalam hal langkah-langah yang harus dilakukan dalam setiap tahap proses penjaringan aspirasi masyarakat, mulai dari tahap persiapan, pelaksanaan, penyusunan laporan sampai tindak lanjut yang harus dilakukan sampai penyusunan format laporan hasil penjaringan aspirasi masyarakat. Draf pemetaan model dan penataan proses tersebut kemudian dijadikan sebagai draf awal yang kemudian disempurnakan melalui kegiatan focus group discussion (FGD)

\section{Hasil Focus Group Discussion (FGD)}

Untuk dapat merumuskan model yang tepat dalam penjaringan aspirasi masyarakat DPRD Kabupaten Purworejo, maka diadakan Focus Group Discussion (FGD), yang diikuti oleh yang diikuti oleh anggota dewan aktif dari 2 daerah pemilihan, mantan anggota DPRD, sekretariat Dewan, pakar politik dari UGM dan perwakilan masyarakat. Dari hasil kegiatan FGD dapat disimpulkan adanya beberapa hal yang patut dipertimbangkan untuk menjadi model penjaringan aspirasi masyarakat, yaitu:
1. Pengaturan mekanisme kegiatan reses

2. Pemetaan konstituen dalam jaring aspirasi masyarakat.

3. Penataan proses pelaksanaan jaring aspirasi masyarakat pada masa reses

4. Standarisasi pelaporan tertulis masa reses

Selain hal-hal tersebut di atas, terungkap dalam FGD bahwa antara kegiatan penjaringan aspirasi masa reses tidak jarang menemukan aspirasi maupun sumber aspirasi yang sama yang disampaikan kegiatan musyawarah perencanaan pembangunan (musrenbang) yang dilaksanakan oleh eksekutif. Oleh karena itu kehadiran pimpinan dan anggota DPRD dalam kegiatan musrenbang perlu di agendakan dengan baik. Hal ini berarti, kehadiran pimpinan dan anggota DPRD tidak hanya sebagai peninjau musrenbang tapi merupakan peserta aktif dan sekaligus sebagai pengawal aspirasi masyarakat yang telah tersalurkan melalu reses anggota dewan. Apabila hal ini dapat dilakukan selain lebih efisien, juga dapat mensingkronkan antara aspirasi masyarakat yang disampaikan kepada anggota DPRD dengan program pembangunan yang disusun oleh fihak eksekutif. Berdasarkan hal tersebut memunculkan wacana kegiatan musrenbang sebagai salah satu model penjaringan aspirasi masyarakat untuk melengkapi beberapa model yang telah berjalan. Hal ini tentunya membutuhkan koordinasi dengan pihak eksekutif.

\section{Hasil Uji Model}

Model alternatif penjaringan aspirasi masyarakat DPRD Kabupaten Purworejo dituangkan dalam bentuk Panduan Penjaringan Aspirasi Masyarakat. Panduan penjaringan aspirasi masyarakat mengatur berbagai ketentuan pelaksanaan penjaringan aspirasi masyarakat yang meliputi tahaptahap kegiatan penjaringan aspirasi, segmentasi konstituen, model analisis. Dalam model ini juga disampaikan format laporan kegiatan penjaringan aspirasi masyarakat khususnya pada masa reses.

Ujicoba dilakukan di dua daerah pilihan (dapil). Satu dapil untuk ujicoba format la- 
poran, sedangkan dapil lain ujicoba proses penjaringan melalui partai politik. Setelah diujicoba kemudian diadakan penilaian terhadap panduan penjaringan aspirasi masyarakat dan format laporan hasil penjaringan aspirasi masyarakat.

\section{Panduan Penjaringan Aspirasi Masyarakat}

Penilai panduan penjaringan aspirasi masyarakat berjumlah 13 orang, terdiri dari 4 orang pimpinan dewan, 4 orang ketua pimpinan komisi, 5 orang ketua fraksi. Aspek yang dinilai meliputi: kejelasan model penjaringan aspirasi, kejelasan langkahlangkah penjaringan aspirasi, kejelasan strategi penjaringan aspirasi, kejelasan sumber informasi penjaringan aspirasi, kejelasan segmentasi konstituen, kejelasan kategorisasi aspirasi, rumusan pernyataan yang komunikatif, serta penggunaan kalimat dan kata yang mudah dipahami. Penilaian menggunakan skala 5, skor minimal 1 dan skor maksimal 5.

Berdasarkan hasil penilaian diperoleh rerata skor terendah adalah pada kejelasan strategi penjaringan aspirasi, yaitu 3,08. Apabila nilai rerata tersebut dikonsultasikan dengan standar penilaian dapat disimpulkan bahwa strategi penjaringan aspirasi masyarakat termasuk dalam kategori cukup, sehingga dapat dipergunakan dengan sedikit perbaikan. Skor tertinggi pada aspek rumusan pernyataan yang komunikatif, yaitu 4,00 . Namun demikian hasil rerata skor total mencapai 3,61, apabila nilai rerata tersebut dikonsultasikan dengan standar penilaian, dapat disimpul kan bahwa panduan penjaringan aspirasi masyarakat termasuk kategori baik dan dapat dipergunakan. Responden selain melakukan penilaian, juga diminta komentar dan saran yang berkaitan panduan penjaringan aspirasi masyarakat.

\section{Format Laporan Penjaringan Aspirasi Masyarakat}

Penilai panduan penjaringan aspirasi masyarakat berjumlah 13 orang, terdiri dari 4 orang pimpinan dewan, 4 orang ketua pimpinan komisi, 5 orang ketua fraksi. Aspek yang dinilai meliputi: isi pendahuluan, hasil penjaringan aspirasi, hasil analisis aspirasi, tindak lanjut hasil penjaringan aspirasi, rumusan pernyataan yang komunikatif, serta Penggunaan kalimat dan kata yang mudah dipahami. Penilaian menggunakan skala 5, skor minimal 1 dan skor maksimal 5.

Berdasarkan tabel hasil penilaian terhadap format laporan penjaringan aspirasi masyarakat di atas diperoleh rerata skor terendah adalah pada hasil penjaringan penjaringan aspirasi dan tindak lanjut hasil penjaringan aspirasi yaitu 3,54.. Apabila nilai rerata tersebut dikonsultasikan dengan standar penilaian dapat dikatakan bahwa hasil penjaringan penjaringan aspirasi dan tindak lanjut hasil penjaringan aspirasi termasuk dalam kategori baik, sehingga dapat dipergunakan tanpa perbaikan. Skor tertinggi pada aspek penggunaan kalimat dan kata yang mudah dipahami, yaitu 4,00. Namun demikian hasil rerata skor total mencapai 3,68, apabila nilai rerata tersebut dikonsultasikan dengan standar penilaian di halaman 20, terlihat bahwa format laporan penjaringan aspirasi masyarakat termasuk kategori baik dan dapat dipergunakan. Responden selain melakukan penilaian, juga diminta komentar dan saran yang berkaitan panduan penjaringan aspirasi masyarakat.

\section{Model Akhir Penjaringan Aspirasi Masyarakat.}

Berdasarkan penilaian responden terhadap model penjaringan aspirasi masyarakat membawa pada beberapa pe-rubahan terhadap format model penjaringan aspirasi masyarakat, meskipun secara umum dinilai baik oleh responden. Beberapa bagian yang kemudian dimasukkan terutama terkait dengan format laporan kegiatan reses terkait dengan 1) Monotoring DPRD terhadap pelaksanaan Program Pembangunan; 2) Evaluasi pelaksanaan program sebelumnya; 3) Kesimpulan akhir penjaringan aspirasi masyarakat.

Berdasarkan hasil penilaian dan berbagai masukan tersebut maka format untuk panduan penjaringan aspirasi masyarakat anggota DPRD Kabupaten Purworejo menjadi sebagai berikut :

1. Panduan penjaring aspirasi masyarakat memuat pendahuluan, model penjaringan aspirasi masyarakat, sifat kegiatan pen- 
jaringan, tahap-tahap kegiatan penjaringan, segmentasi konstituen, dan kategorisasi aspirasi.

2. Format laporan kegiatan reses berisi: pendahuluan, hasil evaluasi program sebelumnya, hasil penjaringan aspirasi masyarakat, hasil analisis aspirasi/isu strategis, tindak lanjut aspirasi, kesimpulan hasil reses, dan penutup

\section{SIMPULAN}

Penjaringan aspirasi masyarakat dapat dilakukan dalam 5 model, yaitu 1) Model penjaringan aspirasi yang dilakukan se-cara perorangan; 2) Model penjaringan aspirasi yang dilakukan melalui Partai Politik; 3) Model penjaringan aspirasi yang dilakukan sesuai dengan komisi yang di duduki; 4) Model penjaringan aspirasi yang dilakukan bersama-sama dengan anggota DPRD di daerah pe-milihan; 5) Model penjaringan aspirasi yang dilakukan bersamaan dengan kegiatan musyawarah pembangunan (musrenbang).

Kegiatan penjaringan aspirasi masyarakat dapat dilakukan secara formal maupun informal. Kegiatan penjaringan aspirasi secara formal artinya kegiatan tersebut telah direncanakan secara secara matang, baik dari segi waktu, tempat, peserta, maupun susunan acara penjaringan aspirasi. Hal ini dapat dilakukan melalui pertemuan-pertemuan resmi yang diko-ordinasikan oleh sekretariat DPRD dan atau Pemerintah Daerah (Pemda). Sedangkan kegiatan penjaringan aspirasi masyarakat secara informal artinya kegiatan tersebut tidak direncanakan se-cara matang, bersifat insidental, tidak terikat waktu, tempat, maupun sumber informasi. Kegiatan model kedua ini biasanya dilakukan secara perorangan.

\section{DAFTAR PUSTAKA}

Alfian, 1985. Beberapa Masalah Perubahan Politik Di Indonesia, Jakarta : Rajawali Press.

Bernardin John H dan Joyce E.A Russel, 2001, dalam Faustino Cpordaso Gomes, Manajemen Sumber Daya Manusia. Yogyakarta: Andi

Certo, Samuel C.2000. Modernmanagement: diversity, quality, ethics, \& the global environment. New Jersey: Printice Hall

Encyclopedia of educational evaluation. 1975. San Frasisco: Jossey-Bass Publishers

Imawan Riswanda. 2000. "Representasi DPRD dan penyebaran aspirasi masyarakat" (Makalah), Jurusan Ilmu Politik UGM, Yogyakarta

J.Kristiadi" "kata pengantar", dalam Koirudin, 2004. Profil Pemilu 2004 (Evaluasi Pelaksanaan, Hasil dan Perubahan Peta Politik Nasional Pasca Pemilu Legislatif 2004), Yogyakarta : Pustaka Pelajar.

Olson David M. 1974. Democratic legislative, a comparative view (Politic Series). New York: Armonk.

Plomp,T. 1997. Development research on/in educational development. University of Twente. Netherlands

Sudiyono, A. 2003. Pengantar evaluasi pendidikan. Jakarta: PT Raja Grafindo Persada

Witkin, B.R. 1984. Assessing need in educational and social programs. San Frasisco: Jossey-Bass Publisher 